\title{
Accuracy of Portable Hardness Testers
}

\author{
Alan Vaško ${ }^{1}$, Ján Sovík ${ }^{1}$, Zuzana Sedliačková ${ }^{2}$ \\ ${ }^{1}$ Department of Materials Engineering, Faculty of Mechanical Engineering, University of Žilina, Univerzitná 8215/1, 010 \\ 26 Žilina, Slovakia. E-mail: alan.vasko@fstroj.uniza.sk \\ ${ }^{2}$ Department of Applied Mathematics, Faculty of Mechanical Engineering, University of Žilina, Univerzitná 8215/1, 010 \\ 26 Žilina, Slovakia. E-mail: zuzana.sedliackova@fstroj.uniza.sk
}

\begin{abstract}
Hardness tests enable to determine one of the main mechanical properties of the material, namely hardness. For hardness testing, it is possible to use either conventional desk hardness testers or the currently increasingly used portable hardness testers. The paper is focused on determination of the accuracy and reliability of static (desk) and dynamic (portable) hardness testers. The paper deals with the measurement of hardness of calibration hardness plates by 4 different methods (Brinell, Vickers, Rockwell and Leeb) with using 5 different hardness testers (3 desk and 2 portable). The hardness values measured by the different hardness testers were compared to the reference hardness listed in the calibration hardness plates and consequently, the accuracy of these measurements was evaluated. The aim of the work has been to determine the accuracy and reliability of portable hardness testers in comparison with desk hardness testers.
\end{abstract}

Keywords: Hardness, Brinell, Vickers, Rockwell, Leeb

\section{Introduction}

Hardness is a mechanical property of a material defined as the resistance of a material to the permanent deformation of its surface caused by the effect of a geometrically defined body. In the hardness test, the surface of the test material is mechanically loaded by the pressure of the foreign body from the hard material and the result of this action is quantitatively expressed as the hardness value. Due to their simplicity and applicability even when other tests cannot be used, hardness tests are advantageous and widely used. The metal is not damaged in this test as in most mechanical tests, because only a small volume on the surface of the tested metal is affected [1-3].

Nowadays, several methods for hardness testing are used in practice. Hardness tests are divided:

- according to the principle (indentation, rebound, scratch and pendulum methods),

- according to the speed of the loading force (static and dynamic methods),

- according to the purpose of hardness measurement (macro and microhardness tests) [4-6].

According to the principle, indentation and rebound methods are most widely used. The principle of indentation methods consists in pushing the indentor (ball, pyramid, cone) of steel, carbide or diamond into the test material, where the criterion for determination of hardness is the size of the indentation (Brinell, Vickers, Rockwell and Knoop method). The principle of rebound methods consists in rebounding of the falling body of a certain shape and weight from the test material, where the criterion for determination of hardness is the height of rebound (Shore method) or the energy loss (Leeb method) $[7,8]$.
In static methods, the test material is loaded slowly, continuously, with a uniformly increasing load (Brinell, Vickers, Rockwell and Knoop method); in dynamic methods, the load increases suddenly, by impact (Leeb method).

For laboratory hardness testing, there are usually used desk hardness testers which use static methods. For exterior hardness testing, there are increasingly used universal portable hardness testers that use dynamic methods. These hardness testers enable the measured hardness to be converted to all common hardness scales (HB, HV, HRB, HRC, HS) as well as the orientation tensile strength $\mathrm{R}_{\mathrm{m}}$ [9-15]. For this reason, the paper deals with comparing the accuracy and reliability of static (desk) and dynamic (portable) hardness testers.

\section{Experimental material and methods}

Hardness tests were carried out at the Department of Materials Engineering, Faculty of Mechanical Engineering, University of Žilina.

The following methods were used for experiments (hardness tests) -3 static methods (Brinell, Vickers and Rockwell) and 1 dynamic method (Leeb).

Five hardness testers were used for experiments:

- for Brinell hardness test - desk hardness tester CV-3000LDB;

- for Vickers hardness test - desk hardness tester HPO250/AQ;

- for Rockwell hardness test - desk hardness tester RR-1D/AQ;

- for Leeb hardness test - portable hardness testers TH170 and TH1100 (Fig. 1). 

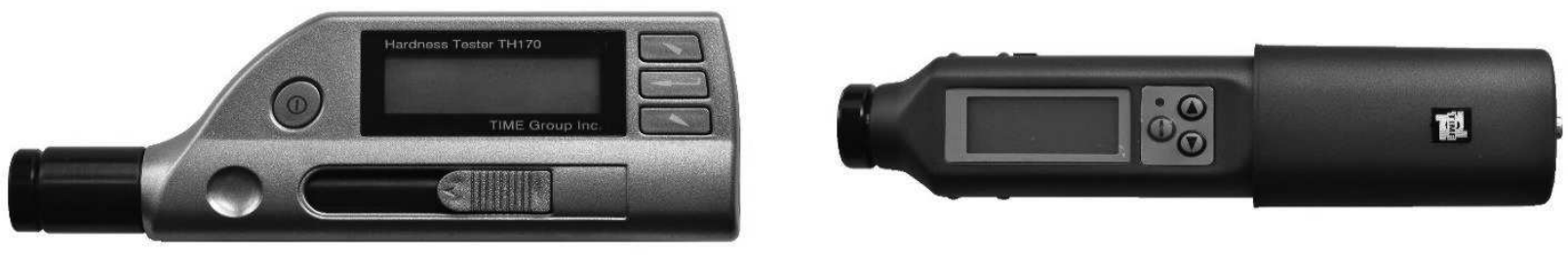

Fig. 1 Portable hardness testers used for experiments - TH170 and TH1100

Four hardness calibration plates were used as experimental material for hardness tests:

- for Brinell hardness test - hardness plate with reference hardness 97.4 HBW 5/250;

- for Vickers hardness test - hardness plate with reference hardness 710 HV 30;

- for Rockwell hardness test - hardness plate with reference hardness 64.4 HRC;

- for Leeb hardness test - hardness plate with reference hardness 778 HLD.

The following conditions were used for hardness tests:

- for Brinell hardness test (according to STN EN ISO 6506-1) - carbide ball with diameter $\mathrm{D}=5$ $\mathrm{mm}$, test load $\mathrm{F}=250 \mathrm{kp}(2452.5 \mathrm{~N})$, loading time $\mathrm{t}=10 \mathrm{~s}=>\mathrm{HBW} 5 / 250 / 10$;

- for Vickers hardness test (according to STN EN ISO 6507-1) - diamond regular quadrilateral pyramid, test load $\mathrm{F}=30 \mathrm{kp}(294.3 \mathrm{~N})$, loading time $\mathrm{t}=10 \mathrm{~s}=>\mathrm{HV} 30 / 10$;

- for Rockwell hardness test (according to STN EN ISO 6508-1) - diamond cone, test load F = $150 \mathrm{kp}(1471.5 \mathrm{~N})$, loading time $\mathrm{t}=6 \mathrm{~s}=>\mathrm{HRC}$;

- for Leeb hardness test (according to STN EN ISO 16859-1) - carbide ball with diameter D = $3 \mathrm{~mm}=>$ HLD.
Each calibration hardness plate was subjected to $\mathrm{n}=5$ measurements using a desk hardness tester and another $n$ $=5$ measurements using portable hardness testers. The average value $\overline{\mathrm{H}}$ and standard deviation $\mathrm{s}_{\mathrm{H}}[16,17]$ were calculated from the measured values $\mathrm{H}_{\mathrm{i}}$ according to the formulas:

$$
\begin{gathered}
\overline{\mathbf{H}}=\frac{\sum_{\mathrm{i}=1}^{\mathrm{n}} \mathrm{H}_{\mathrm{i}}}{\mathrm{n}} \\
\mathbf{S}_{\mathrm{H}}=\sqrt{\frac{1}{\mathrm{n}-1} \sum_{\mathrm{i}=1}^{\mathrm{n}}\left(\mathbf{H}_{\mathrm{i}}-\overline{\mathbf{H}}\right)^{2}}
\end{gathered}
$$

Where:

n ... number of measurements [-],

$\mathrm{H}_{\mathrm{i}} \ldots$ measured values of hardness $[-]$.

From the average hardness $\overline{\mathrm{H}}$ and reference hardness $\mathrm{H}_{\text {ref }}$ listed on the calibration hardness plate, the measurement inaccuracy $\mathrm{N}$ was calculated according to the formula

$$
\mathbf{N}=\frac{\overline{\mathbf{H}}-\mathbf{H}_{\text {ref }}}{\mathbf{H}_{\text {ref }}} \cdot \mathbf{1 0 0}[\%]
$$

Where:

$\overline{\mathrm{H}}$... average hardness [-],

$\mathrm{H}_{\text {ref }} \ldots$ reference hardness from the calibration hardness plate $[-]$.

\section{Experimental results and discussion}

The results of hardness measurement on the hardness plate for Brinell hardness test are given in Tab. 1. Desk hardness tester CV-3000LDB and portable hardness testers TH170 and TH1100 were used for measurement.

Tab. 1 Results of Brinell hardness test

\begin{tabular}{|c|c|c|c|c|}
\hline Hardness tester & \multicolumn{2}{|c|}{ CV-3000LDB } & TH170 & TH1100 \\
\hline Measurement No & $\mathrm{d}(\mathrm{mm})$ & HBW5/250/10 & HB (HLD) & HB (HLD) \\
\hline 1 & 1.78 & 98 & 91 & 91 \\
\hline 2 & 1.80 & 95 & 92 & 93 \\
\hline 3 & 1.78 & 98 & 96 & 90 \\
\hline 4 & 1.79 & 96 & 97 & 91.6 \\
\hline 5 & 1.80 & 95 & 92 & 2.41 \\
\hline$\overline{\mathrm{H}}$ & & 96.4 & 93.6 & -5.95 \\
\hline $\mathrm{S}_{\mathrm{H}}$ & & 1.52 & 2.70 & -3.90 \\
\hline
\end{tabular}




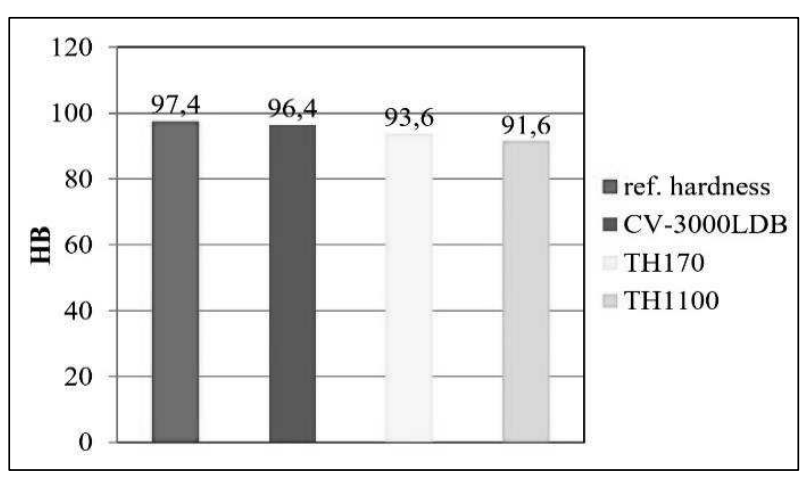

Fig. 2 Comparison of measured Brinell hardness with the reference hardness
A comparison of the results of Brinell hardness test is shown in Fig. 2. The hardness measured by the desk hardness tester differs from the reference hardness minimally $(-1.03 \%)$. The hardness determined by the portable hardness testers differs from the reference hardness by -3.90 $\%$, respectively $-5.95 \%$. The values measured by the desk hardness tester show less inaccuracy than the values measured by the portable hardness testers (Tab. 1).

The results of hardness measurement on the hardness plate for Vickers hardness test are given in Tab. 2. Desk hardness tester HPO250/AQ and portable hardness testers TH170 and TH1100 were used for measurement.

Tab. 2 Results of Vickers hardness test

\begin{tabular}{|c|c|c|c|c|}
\hline Hardness tester & \multicolumn{2}{|c|}{ HPO250/AQ } & TH170 & TH1100 \\
\hline Measurement No & $\mathrm{d}(\mathrm{mm})$ & $\mathrm{HV} 30 / 10$ & HV (HLD) & HV (HLD) \\
\hline 1 & 0.275 & 736 & 742 & 698 \\
\hline 2 & 0.275 & 736 & 706 & 689 \\
\hline 3 & 0.276 & 730 & 731 & 691 \\
\hline 4 & 0.274 & 741 & 735 & 697.6 \\
\hline 5 & 0.274 & 741 & 740 & 7.67 \\
\hline $\mathrm{H}$ & & 736.8 & 14.52 & -1.75 \\
\hline $\mathrm{S}$ & & 4.55 & +2.93 & \\
\hline $\mathrm{N}(\%)$ & & +3.77 & \\
\hline
\end{tabular}

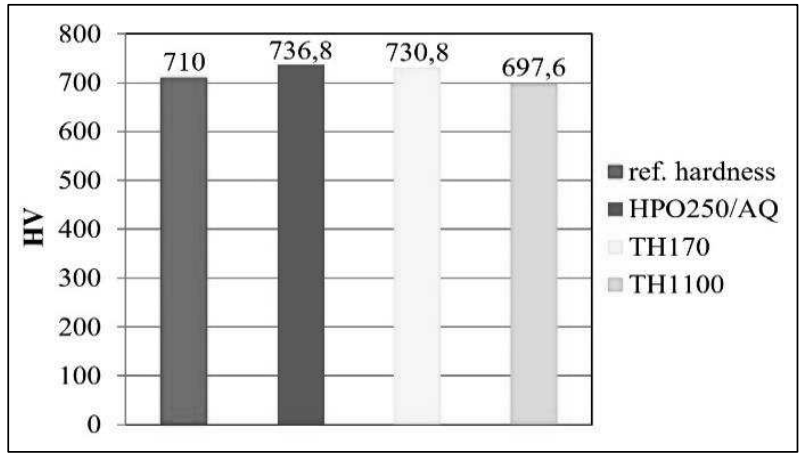

Fig. 3 Comparison of measured Vickers hardness with the reference hardness
A comparison of the results of Vickers hardness test is shown in Fig. 3. The hardness measured by the desk hardness tester differs from the reference hardness by $+3.77 \%$. The hardness determined by the portable hardness testers differs from the reference hardness by +2.93 $\%$, respectively $-1.75 \%$. The values measured by the portable hardness testers show less inaccuracy than the values measured by the desk hardness tester (Tab. 2).

The results of hardness measurement on the hardness plate for Rockwell hardness test are shown in Tab. 3. Desk hardness tester RR-1D/AQ and portable hardness testers TH170 and TH1100 were used for measurement.

Tab. 3 Results of Rockwell hardness test

\begin{tabular}{|c|c|c|c|}
\hline Hardness tester & RR-1D/AQ & TH170 & TH1100 \\
\hline Measurement No & HRC & HRC (HLD) & 60.4 \\
\hline 1 & 64.1 & 62.4 & 59.0 \\
\hline 2 & 64.8 & 58.6 & 60.9 \\
\hline 3 & 64.6 & 61.6 & 60.1 \\
\hline 4 & 64.5 & 60.5 & 60.3 \\
\hline 5 & 64.7 & 63.2 & 60.2 \\
\hline $\bar{H}$ & 64.5 & 61.3 & 0.71 \\
\hline $\mathrm{s}_{\mathrm{H}}$ & 0.27 & 1.79 & -6.52 \\
\hline $\mathrm{N}(\%)$ & +0.22 & -4.81 & \\
\hline
\end{tabular}




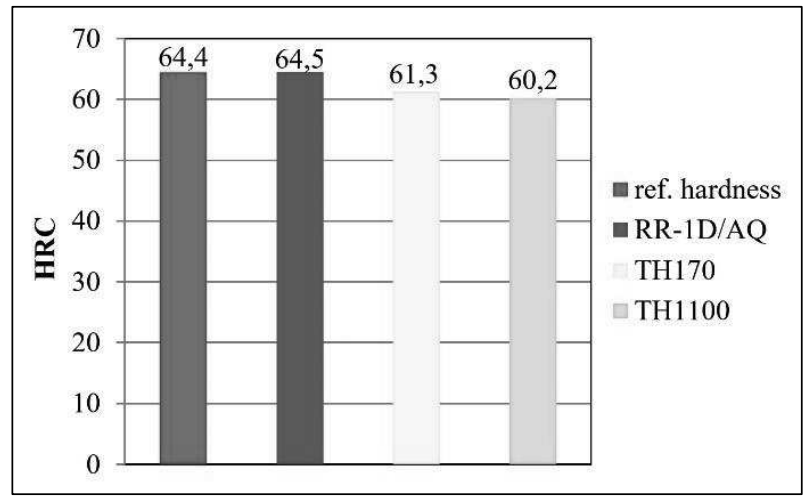

Fig. 4 Comparison of measured Rockwell hardness with the reference hardness

A comparison of the results of Rockwell hardness test is shown in Fig. 4. The hardness measured by the desk

Tab. 4 Results of Leeb hardness test

\begin{tabular}{|c|c|c|}
\hline Hardness tester & TH170 & TH1 100 \\
\hline Measurement No & HLD & 784 \\
\hline 1 & 777 & 784 \\
\hline 2 & 781 & 785 \\
\hline 3 & 785 & 780 \\
\hline 4 & 782 & 783 \\
\hline 5 & 780 & 783.2 \\
\hline$\overline{\mathrm{H}}$ & 781.0 & 1.94 \\
\hline $\mathrm{S}_{\mathrm{H}}$ & 2.92 & +0.64 \\
\hline $\mathrm{N}(\%)$ & +0.38 & \\
\hline \multicolumn{2}{|c|}{ reference hardness $\mathrm{H}_{\text {ref }}$ from the calibration hardness plate => 778 HLD } \\
\hline
\end{tabular}

A comparison of the results of Leeb hardness test is shown in Fig. 5. The hardness determined by the portable hardness testers differs from the reference hardness by less than $1 \%(+0.38 \%$, respectively $+0.64 \%)$ (Tab. 4).

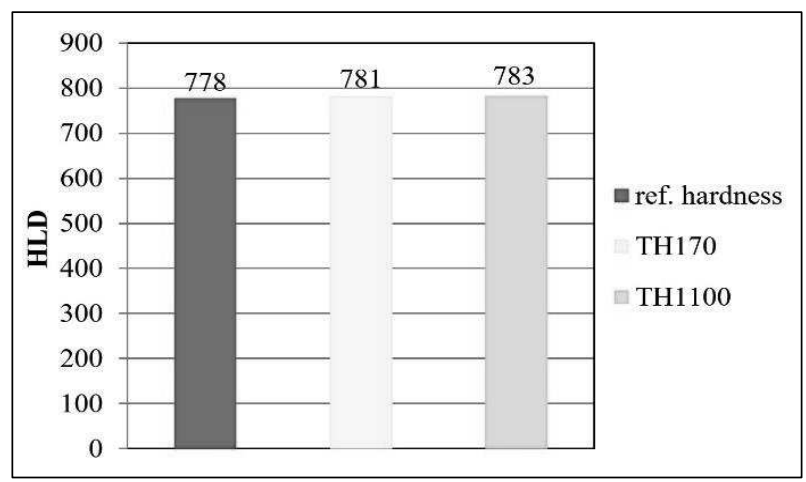

Fig. 5 Comparison of measured Leeb hardness with the reference hardness

Using portable hardness testers, the lowest inaccuracy $\mathrm{N}$ was achieved for Vickers hardness test $(+2.93 \%$ by the hardness tester TH170, respectively $-1.75 \%$ by the hardness tester TH1100), followed by Brinell hardness test ($3.90 \%$ by the hardness tester TH170 and $-5.95 \%$ by the hardness tester TH1100) and by Rockwell hardness test $(-4.81 \%$ by the hardness tester TH170 and $-6.52 \%$ by the hardness tester TH1100). For the Leeb hardness test, hardness tester differs from the reference hardness minimally $(+0.22 \%)$. The hardness determined by the portable hardness testers differs from the reference hardness by $-4.81 \%$, respectively $-6.52 \%$. The values measured by the desk hardness tester show less inaccuracy than the values measured by the portable hardness testers (Tab. 3).

By comparing the desk hardness testers, it was found that the lowest inaccuracy $\mathrm{N}$ (percentage deviation between measured and reference hardness) was achieved by the hardness tester RR-1D/AQ for Rockwell hardness test $(+0.22 \%)$, followed by the hardness tester CV-3000LDB for Brinell hardness test $(-1.03 \%)$ and finally by the hardness tester HPO250/AQ for Vickers hardness test $(+3.77 \%)$.

The results of hardness measurement on the hardness plate for Leeb hardness test are given in Tab. 4. Portable hardness testers TH170 and TH1100 were used for measurement. the inaccuracy of measurement was minimal in both cases $(+0.38 \%$, respectively $+0.64 \%)$.

By comparing the portable hardness testers, it was found that the hardness tester TH170 was more accurate for Brinell hardness test (inaccuracy $-3.90 \%$ ), Rockwell hardness test $(-4.81 \%)$ and Leeb hardness test $(+0.38 \%)$; the hardness tester TH1100 was more accurate only for Vickers hardness test $(-1.75 \%)$.

In the case of Brinell hardness test, the desk hardness tester CV-3000LDB was significantly more accurate (inaccuracy $-1.03 \%$ ) than the portable hardness testers. Similarly, for Rockwell hardness test, the desk hardness tester RR-1D/AQ was significantly more accurate $(+0.22$ $\%)$ compared to the portable hardness testers. Only for Vickers hardness test, the portable hardness testers TH170 and TH1100 were more accurate $(+2.93 \%$, respectively $-1.75 \%$ ) compared to the desk hardness tester HPO250/AQ. In this case, it would be necessary to calibrate the desk hardness tester to increase its accuracy.

\section{Conclusion}

The hardness tests carried out with using desk and portable hardness testers showed that more accurate values of hardness were obtained using desk hardness testers. The accuracy and reliability of portable hardness testers was lower than that of desk hardness testers. This accuracy can be influenced by different method of measur- 
ing and by the need to convert the measured Leeb hardness to other hardness scales. On the other hand, portable hardness testers have several advantages, such as measuring hardness outside the laboratory, measuring large and heavy test specimens (that cannot be measured with desk hardness testers), measuring hardness in different directions, lower cost of hardness testing, etc.

\section{Acknowedgement}

The research has been supported by the Scientific Grant Agency of Ministry of Education, Science, Research and Sport of Slovak Republic, grant project VEGA No. 1/0398/19 and by the Culture and Educational Grant Agency of Ministry of Education, Science, Research and Sport of Slovak Republic, grant projects KEGA No. $049 \check{U} U-4 / 2017$ and 012ŽU-4/2019.

This work has been supported by the project of Operational Program Research and Innovation: Research and development activities of the University of Zilina in the Industry of 21st century in the field of materials and nanotechno-logies, No. 313011T426. The project is cofunding by European Regional Development Fund.

\section{References}

[1] KUHN, H., MEDLIN, D. (2000). ASM Handbook, Vol. 8: Mechanical testing and evaluation. ASM International, Materials Park, Ohio, USA.

[2] CHANDLER, H. (2004). Hardness testing. ASM International, Materials Park, Ohio, USA.

[3] HERRMANN, K. (2011). Hardness testing principles and applications. ASM International, Materials Park, Ohio, USA.

[4] VAŠKO, A., SKOČOVSKÝ, P. (2014). Vlastnosti a použitie kovových materiálov. EDIS, Žilina, Slovakia.

[5] HURTALOVÁ, L., TILlOVÁ, E., CHALUPOVÁ, M. (2013). Changes of matrix microhardness in aluminium cast alloys during hardening. In: 30th Danubia Adria Symposium, pp. 292-293. Primošten, Croatia.

[6] KVASNOVÁ, P., KUČERKA, M., HRUBÝ, D., NOVÁK, D., NOVÁK, V. (2018). Hardness tests and dimensional and shape precision analysis of construction and agricultural machinery components. In: Manufacturing Technology, Vol. 18, No. 6, pp. 943-949. Ústí nad Labem, Czech Republic.
[7] SKOČOVSKÝ, P., BOKŮVKA, O., KONEČNÁ, R., TILlOVÁ, E. (2015). Náuka o materiáli. EDIS, Žilina, Slovakia.

[8] BORKOWSKI, S., ULEWICZ, R. (2009). Laboratorium $z$ materiałoznawstwa dla inżynierów. CWA, Częstochowa, Poland.

[9] GUSYATINSKAYA, N.S. (1997). New portable hardness testers. In: Measurement Techniques, Vol. 40, No. 7, pp. 666-668.

[10] BORGGREEN, K., AUERKARI, P. (2001). Performance of some portable hardness testers. In: Baltica $V$ - Condition and life management for power plants. pp. 559-574. Porvoo, Finland.

[11] SMEJKAL, J. Měření tvrdosti dle ASTM A 95600 . lohy/149/astm956.pdf> $<$ http://www.testima.eu/pri-

[12] ZAŤKO, M., ECKHARDT, E. Metódy merania tvrdosti materiálov a zásady pri vol’be prenosných prístrojov na meranie. <http://www.ssndt.sk/files/ odborne/Zakladne\%20zasady\%201.pdf >

[13] FENG, Z. M., PENG, Z. H., LAN, Z. X., WANG, P. W., PENG, J., WU, J. Y. (2013). Influence factors analysis on measuring error Leeb hardness tester on site. In: Petrochemical Equipment, Vol. 42, No. 1, pp. 84-87. Beijing, China.

[14] HEGAZY, R., MOHAMAD, G., MOHAMAD, M., KHALED, K. M., MOHAMAD, M. I. (2017). Empirical relation between Leeb rebound hardness and tensile strength for austenitic ductile cast iron. In: 13th IMEKO TC5 Conference on the Measurement of Hardness 2017, Helsinki, Finland.

[15] FORMISANO, A., CHIUMIENTO, G., DI LORENZO, G. (2017). Leeb hardness experimental tests on carpentry steels: Surface treatment effect and empirical correlation with strength. In: International Conference of Numerical Analysis and Applied Mathematics 2017, Article number 450004, Thessaloniki, Greece.

[16] DOROCIAKOVÁ, B., POBOČÍKOVÁ, I. (2010). Zbierka úloh z pravdepodobnosti a matematickej štatistiky. EDIS, Žilina, Slovakia.

[17] VOLAUF, P. (2014). Pravdepodobnost' a matematická štatistika. TU, Košice, Slovakia. 